\title{
WYZNACZANIE CHARAKTERYSTYK R $=$ F(T) TAŚM NADPRZEWODNIKOWYCH PIERWSZEJ I DRUGIEJ GENERACJI
}

\author{
Rafal Kwoka $^{1}$, Janusz Kozak ${ }^{2}$, Michal Majka ${ }^{1}$ \\ ${ }^{1}$ Politechnika Lubelska, Instytut Elektrotechniki i Elektrotechnologii, ${ }^{2}$ Instytut Elektrotechniki, Zakład Wielkich Mocy, Pracownia Technologii Nadprzewodnikowych \\ Streszczenie. W artykule przedstawiono eksperymentalnie wyznaczone charakterystyki $R=f(T)$ taśm nadprzewodnikowych pierwszej (1G) $i$ drugiej \\ generacji (2G). W pracy opisano sposób przygotowania próbek taśm nadprzewodnikowych $1 G$ i $2 G$ do badań, opisano metodę pomiarowa oraz \\ przedstawiono wyniki badań eksperymentalnych. \\ Słowa kluczowe: nadprzewodnictwo, taśmy nadprzewodnikowe HTS pierwszej i drugiej generacji, nadprzewodnikowy ogranicznik prądu zwarciowego

\section{DETERMINATION OF $R=F(T)$ CHARACTERISTICS OF THE FIRST AND SECOND GENERATION SUPERCONDUCTING TAPES}

Abstract. The experimental characteristics $R=f(T)$ of the first $(1 G)$ and the second $(2 G)$ generation HTS tapes are presented in this paper. The paper describes samples preparation of $1 G$ and $2 G$ superconducting tapes, describes the measurement method and the results of experimental studies.

Keywords: superconductivity, $1^{\text {st }}$ and $2^{\text {nd }}$ generation HTS tape, superconducting fault current limiter

\section{Wstęp}

Obecnie produkowane taśmy nadprzewodnikowe pierwszej (1G) i drugiej generacji (2G) wytwarzane są w odcinkach o dhugości kilkuset metrów, a koszt ich wytwarzania jest coraz niższy. Taśmy nadprzewodnikowe znajdują zastosowanie w elektromagnesach, transformatorach nadprzewodnikowych, organicznikach prądów zwarciowych, silnikach elektrycznych czy też generatorach $[2,3,4,5,8,9]$. Taśmy nadprzewodnikowe drugiej generacji bez stabilizatora miedzianego mają rezystancję w stanie rezystywnym wystarczająco dużą do budowy skutecznie działających ograniczników prądów zwarciowych.

Producenci taśm nadprzewodnikowych podają podstawowe parametry taśm nadprzewodnikowych takie jak szerokość taśmy, minimalną średnicę gięcia czy też wartość prądu krytycznego $[4,5,8]$, nie podają jednak wartości rezystancji taśm mierzonych W różnych temperaturach. Charakterystyka $R=\mathrm{f}(T)$ taśmy nadprzewodnikowej jest niezbędna do projektowania nadprzewodnikowych ograniczników prądu zwarciowego i obliczeń modeli ograniczników metodą elementów skończonych.

\section{Taśmy nadprzewodnikowe I i II generacji}

Podział taśm nadprzewodnikowych na pierwszą i drugą generację wynika $\mathrm{z}$ różnicy $\mathrm{w}$ ich budowie wewnętrznej i technologii ich wytwarzania. Taśmy nadprzewodnikowe pierwszej generacji (1G) wytwarzane są metodą rurowoproszkową [5]. Taśmy te mają budowę kompozytową i składają się $\mathrm{z}$ kilkudziesięciu włókien nadprzewodnika (Bi-2212 lub Bi-2223) umieszczonych wewnątrz srebrnej matrycy, rysunek $1[5]$.

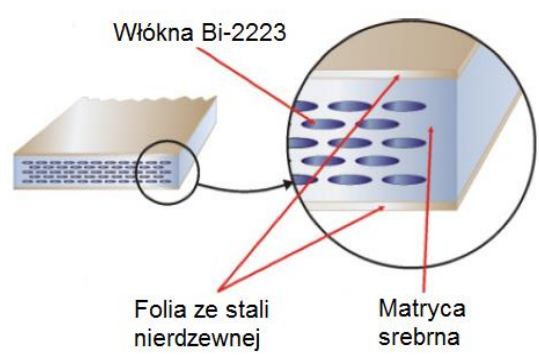

Rys. 1. Budowa taśmy nadprzewodnikowej pierwszej generacji [7]

Matrycą może być czyste srebro, stopy srebra ze złotem lub stopy innych metali [1]. Materiał matrycy ma decydujący wpływ na wytrzymałość mechaniczną taśmy. Obecnie głównym producentem taśm nadprzewodnikowych pierwszej generacji jest firma Sumitomo Electric. Parametry taśmy DI-BSCCO produkowanej przez Sumitomo zamieszczono w tabeli 1. Taśmy HTS $1 \mathrm{G}$ typu HT (HT-SS, HT-CA, HT-NX) charakteryzują się wzmocnioną mechaniczne konstrukcją, dzięki dwustronnemu pokryciu warstwą stali nierdzewnej, miedzi lub niklu. Dodatkowo taśma jest uszczelniona obustronnie lutem w celu ograniczenia wnikania cieczy kriogenicznej do wnętrza taśmy [11].

Tabela 1. Parametry taśm HTS pierwszej generacji DI-BSCCO produkcji Sumitomo Electric [11]

\begin{tabular}{|l|c|}
\hline \multicolumn{2}{|c|}{ Taśmy pierwszej generacji DI-BSCCO firmy Sumitomo Electric } \\
\hline Szerokość & $2,8 \div 4,5 \mathrm{~mm}$ \\
\hline Długość odcinkowa, & $500 \div 1500 \mathrm{~m}$ \\
\hline Grubość & $0,23 \div 0,34 \mathrm{~mm}$ \\
\hline Granica plastyczności & $130 \div 400 \mathrm{MPa}$ \\
\hline Minimalna średnica gięcia & $40 \div 80 \mathrm{~mm}$ \\
\hline Materiał powłoki zewnętrznej & $\begin{array}{c}\text { stal nierdzewna }-20 \mu \mathrm{m} \\
\text { miedź }-50 \mu \mathrm{m} \\
\text { nikiel }-30 \mu \mathrm{m}\end{array}$ \\
\hline Prąd krytyczny $I_{C(77 \mathrm{~K})}$ & $60 \div 200 \mathrm{~A}$ \\
\hline
\end{tabular}

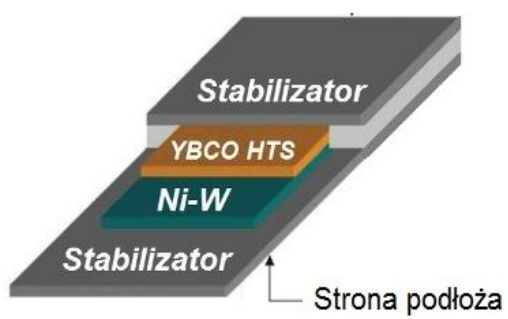

Rys. 2. Struktura taśmy HTS 2G firmy American Superconductor [10]

Tabela 2. Parametry taśm nadprzewodnikowych drugiej generacji produkowanych przez firme American Superconductor [10]

\begin{tabular}{|l|c|}
\hline \multicolumn{2}{|c|}{ Taśmy HTS drugiej generacji firmy American Superconductor } \\
\hline Szerokość & $4,24 \div 12,3 \mathrm{~mm}$ \\
\hline Długość odcinkowa & $300 \div 800 \mathrm{~m}$ \\
\hline Grubość & $0,18 \div 0,44 \mathrm{~mm}$ \\
\hline Granica plastyczności, MPa & $150 \div 200 \mathrm{MPa}$ \\
\hline Minimalna średnica gięcia, mm & $40 \div 250 \mathrm{~mm}$ \\
\hline Materiał powłoki zewnętrznej & $\begin{array}{c}\text { stal nierdzewna }-25 \mu \mathrm{m} \\
\text { miedź }-50 \mu \mathrm{m}\end{array}$ \\
\hline Prąd krytyczny $I_{C}$ w temp. 77 K & $60 \div 200 \mathrm{~A}$ \\
\hline
\end{tabular}


Taśmy nadprzewodnikowe drugiej generacji (taśmy HTS 2G) składają się z szeregu warstw, z których wyróżniamy: warstwę podłoża odpowiadającą za parametry mechaniczne taśmy, kilku warstw buforowych, warstwy nadprzewodnika, warstwy srebra i warstwy stabilizatora miedzianego [2, 6, 12]. Strukturę taśm nadprzewodnikowych HTS drugiej generacji, której parametry zamieszczono $\mathrm{w}$ tabeli 2 i tabeli 3 przedstawiają rysunki 2 i 3 .

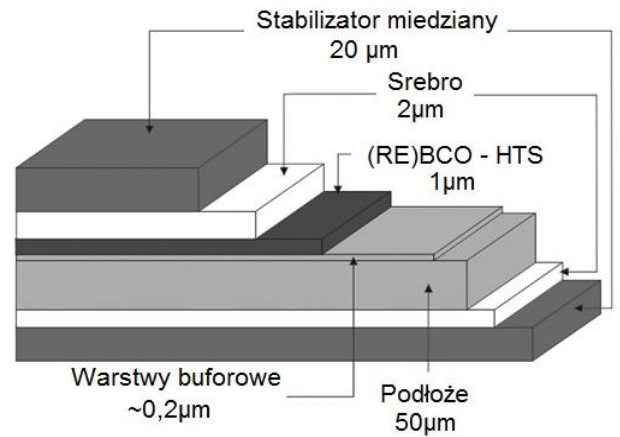

Rys. 3. Przekrój poprzeczny taśmy HTS 2 G firmy SuperPower

Tabela 3. Parametry taśm nadprzewodnikowych drugiej generacji produkowanych przez firme SuperPower [12]

\begin{tabular}{|l|c|}
\hline \multicolumn{2}{|c|}{ Taśmy HTS drugiej generacji firmy SuperPower } \\
\hline Szerokość & $3 \div 12$ \\
\hline Długość odcinkowa & $300 \div 600 \mathrm{~m}$ \\
\hline Grubość & $0,055 \div 0,105 \mathrm{~mm}$ \\
\hline Granica plastyczności & $650 \div 1200 \mathrm{MPa}$ \\
\hline Minimalna średnica gięcia & $11 \div 25 \mathrm{~mm}$ \\
\hline Materiał powłoki zewnętrznej & miedź $-50 \mu \mathrm{m}$ \\
\hline Prąd krytyczny $I_{C}$ w temp. $77 \mathrm{~K}$ & $75 \div 300 \mathrm{~A}$ \\
\hline
\end{tabular}

\section{Przygotowanie próbek taśm HTS 1G i 2G do wyznaczania charakterystyk $R=f(T)$}

Próbka taśmy nadprzewodnikowej przygotowana do wyznaczenia charakterystyki $R=\mathrm{f}(T)$ metodą czteroprzewodową ma przylutowane dwa doprowadzenia prądowe (I-, I+) i dwa napięciowe $(\mathrm{V}-, \mathrm{V}+)$ (rys. 4). Rozstaw przewodów pomiarowych wynosi $100 \mathrm{~mm}$. Lutowanie przewodów pomiarowych do taśmy nadprzewodnikowej wykonano lutownicą na gorące powietrze $\mathrm{w}$ temperaturze zgodnie $\mathrm{z}$ zaleceniami producenta taśm nadprzewodnikowych (tabela 4). Do lutowania zastosowano pastę lutowniczą $\mathrm{Sn} 62 \mathrm{~Pb} 36 \mathrm{Ag} 2$ o temperaturze topnienia $179^{\circ} \mathrm{C}$.

Tabela 4. Zalecenia firmy SuperPower dotyczące lutowania taśm HTS [12]

\begin{tabular}{|l|c|c|}
\hline & SCS & SF \\
\hline Temperatura lutowania, ${ }^{\circ} \mathrm{C}$ & 200 & 195 \\
\hline Max. temp. lutowania, ${ }^{\circ} \mathrm{C}$ & 240 & 240 \\
\hline
\end{tabular}

W celu wyznaczenia charakterystyki $R=\mathrm{f}(T)$ został wykonany uchwyt dla próbek taśm nadprzewodnikowych. Uchwyt próbki taśmy wykonany $\mathrm{z}$ kompozytu szklano - epoksydowego do którego zamocowane są dwa płaskowniki miedziane izolowane folią poliamidową o grubości $50 \mu \mathrm{m}$. W płaskownikach wykonane są rowki w miejscach, w których do próbki przylutowane są przewody pomiarowe. Po skręceniu uchwytu taśma nadprzewodnikowa przylega $\mathrm{z}$ obu stron do płaskowników, próbka jest izolowana elektrycznie. Temperatura taśmy nadprzewodnikowej mierzona była kriogenicznym czujnikiem temperatury Cernox umieszczonym w otworze bloku miedzianego.

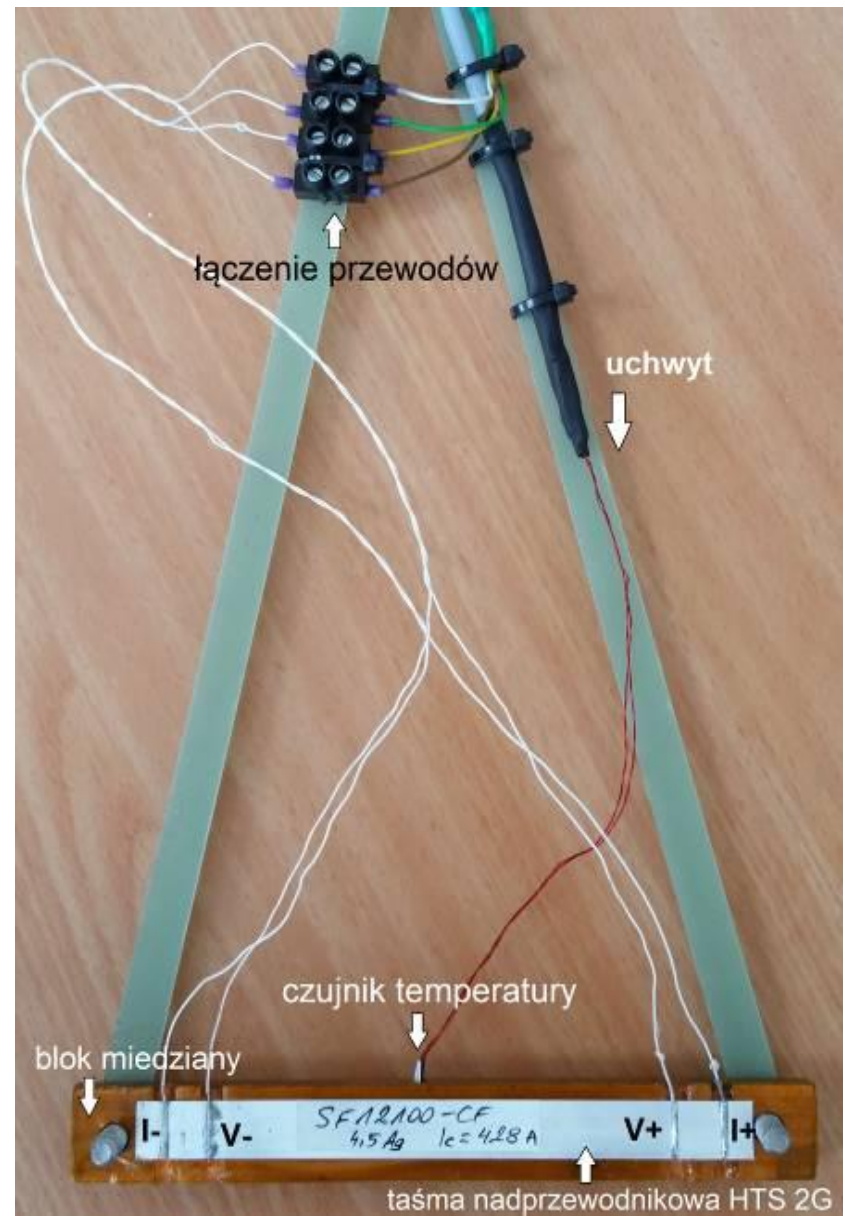

Rys. 4. Próbka taśmy HTS $2 G$ w uchwycie

Charakterystyki wyznaczono dla kilku próbek taśm nadprzewodnikowych pierwszej i drugiej generacji. Wybrane próbki przedstawiono na rysunkach:

- $5 \mathrm{a}, 5 \mathrm{~b}$ - taśmy $1 \mathrm{G}$,

- $6 c, 6 d$ - taśmy $2 \mathrm{G}$ typu SCS ze stabilizatorem miedzianym,

- $7 \mathrm{e}, 7 \mathrm{f}$ - taśmy $2 \mathrm{G}$ typu SF bez stabilizatora miedzianego.

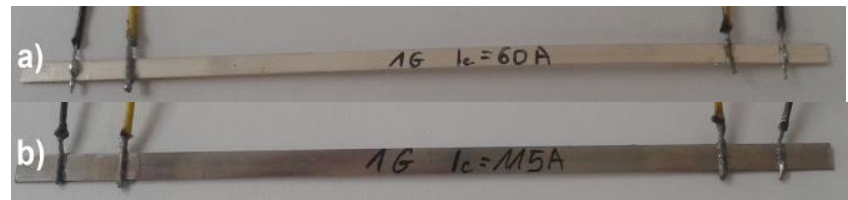

Rys. 5. Próbki taśm HTS pierwszej generacji: a) taśma typu AMSC HSW $\left(I_{c}=60 \mathrm{~A}\right)$ b) taśma typu AMSC HSPW (Ic = 115 A)

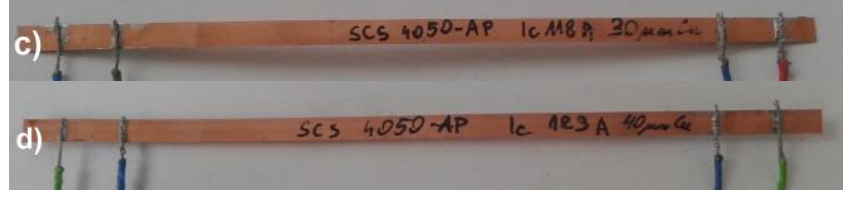

Rys. 6. Próbki taśm HTS drugiej generacji: c) taśma typu SCS $\left(I_{c}=118\right.$ A), d) taśma typu $\operatorname{SCS}\left(I_{c}=123 \mathrm{~A}\right)$

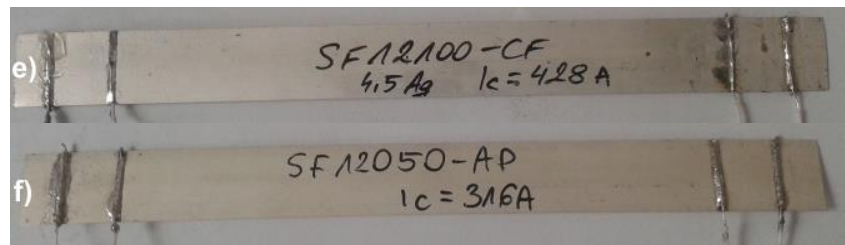

Rys. 7. Próbki taśm HTS 2G: e) typu SF12100-CF $\left(I_{c}=428\right.$ A) if) typu SF12050-AP $\left(I_{c}=316 \mathrm{~A}\right)$ 


\section{Układ pomiarowy}

Do wyznaczenia charakterystyk $R=\mathrm{f}(T)$ taśm nadprzewodnikowych zaprojektowano i wykonano układ pomiarowy składający się z miernika temperatury LakeShore Model 218, układu sterowania, komputera pomiarowego $\mathrm{z}$ oprogramowaniem NI LabView, karty pomiarowej USB-6343 oraz kriostatu $\mathrm{z}$ ciekłym azotem do schłodzenia próbki (rysunek 8). Uproszczony schemat układu pomiarowego przedstawiono na rys. 9 .
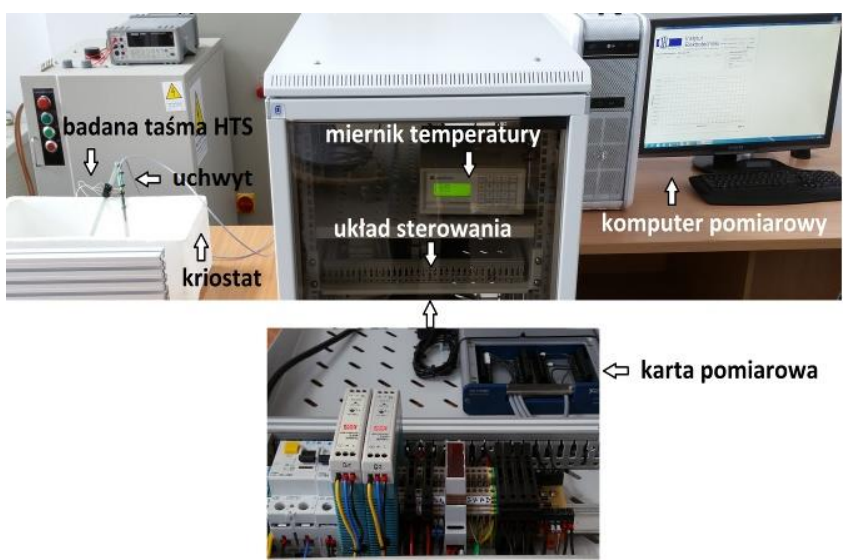

karta pomiarowa

Rys. 8. Laboratoryjny uktad pomiarowy

Wszystkie urządzenia laboratoryjnego układu pomiarowego są skomunikowane $\mathrm{z}$ komputerem. Oprogramowanie napisane w środowisku LabView umożliwia wykonanie pomiarów, wykreślenie charakterystyki oraz zapisanie rezultatów.

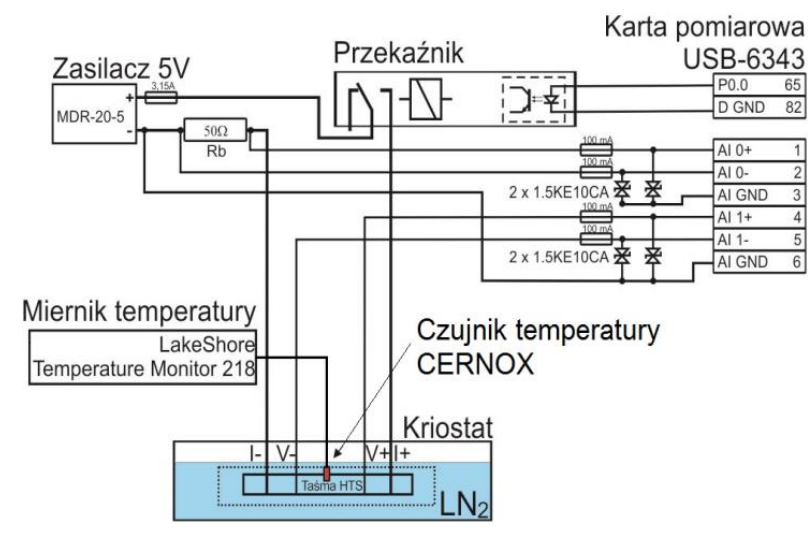

Rys. 9. Schemat układu pomiarowego

\section{Wyznaczanie charakterystyk $R=f(T)$ taśm nadprzewodnikowych 1G i $2 \mathrm{G}$}

Wykonano serie pomiarów taśm nadprzewodnikowych, których najważniejsze parametry zestawiono w tabeli 6 .

Tabela 6. Parametry zastosowanych taśm nadprzewodnikowych HTS [10, 12]

\begin{tabular}{|c|c|c|c|c|c|c|}
\hline \multirow{2}{*}{ Taśma HTS } & $\begin{array}{c}\text { SF 12050 } \\
\text { AP }\end{array}$ & $\begin{array}{c}\text { SF 12100 } \\
\text { CF }\end{array}$ & $\begin{array}{c}\text { SCS 4050 } \\
\text { AP }\end{array}$ & $\begin{array}{c}\text { SCS 4050 } \\
\text { AP }\end{array}$ & $\begin{array}{c}\text { AMSC } \\
\text { HSW }\end{array}$ & $\begin{array}{c}\text { AMSC } \\
\text { HSPW }\end{array}$ \\
\cline { 2 - 7 } & $2 \mathrm{G}$ & $2 \mathrm{G}$ & $2 \mathrm{G}$ & $2 \mathrm{G}$ & $1 \mathrm{G}$ & $1 \mathrm{G}$ \\
\hline Szerokość taśmy, mm & 12 & 12 & 4 & 4 & 4 & 4 \\
\hline $\begin{array}{c}\text { Grubość warstwy } \\
\text { srebra, } \mu \mathrm{m}\end{array}$ & 2 & 4,5 & 2 & 2 & - & - \\
\hline $\begin{array}{c}\text { Grubość warstwy } \\
\text { miedzi, } \mu \mathrm{m}\end{array}$ & - & - & 30 & 40 & - & - \\
\hline Prąd krytyczny, A & 316 & 428 & 118 & 123 & 60 & 118 \\
\hline
\end{tabular}

Po schłodzeniu uchwytu z próbką taśmy nadprzewodnikowej w kąpieli ciekłym azotem do temperatury $77 \mathrm{~K}$ (rysunek 10) uchwyt został wyjęty z kriostatu w celu powolnego ogrzania. Schłodzoną próbkę ogrzewano do temperatury pokojowej. Podczas jej ogrzewania mierzona była jej rezystancja i temperatura w zakresie od 77 do $300 \mathrm{~K}$. Wyniki pomiarów rejestrowano przy użyciu programu napisanego w środowisku LabView (rysunek 11). Program umożliwia odczyt temperatury z miernika LakeShore Temperature Monitor 218 przez port GPIB, pomiar rezystancji próbki taśmy metodą czteroprzewodową oraz zapis wyników do pliku *.xls.

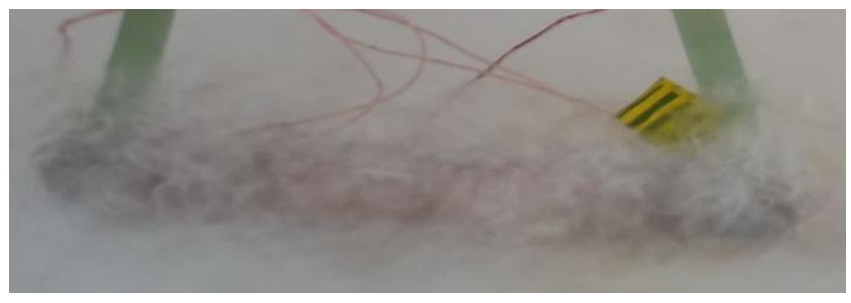

Rys. 10. Chłodzenie próbki w ciektym azocie
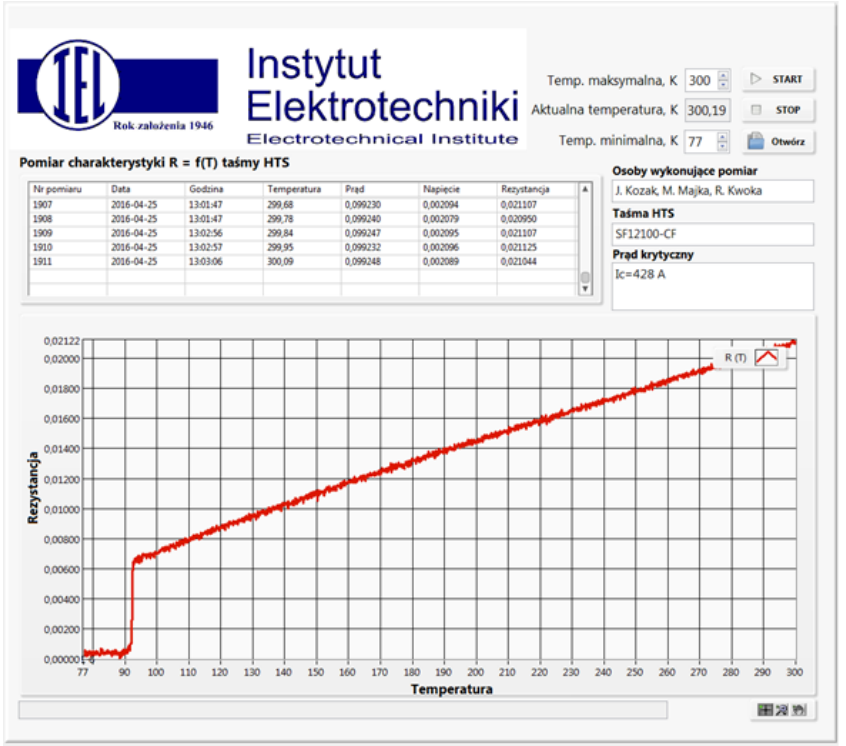

Rys. 11. Program napisany w środowisku LabView do pomiaru charakterystyki $R=f(T)$ taśm nadprzewodnikowych

Otrzymane wyniki wyznaczonych charakterystyk $R=\mathrm{f}(T)$ taśm nadprzewodnikowych zaprezentowano na rysunku 12 . Rezystancja taśm zmierzona w temperaturze $77 \mathrm{~K}$ jest bliska zeru. $\mathrm{Na}$ charakterystyce widoczne jest przejście nadprzewodnika ze stanu nadprzewodzącego do stanu rezystywnego po przekroczeniu temperatury krytycznej. Najmniejszą rezystancję w stanie rezystywnym uzyskały taśmy $1 \mathrm{G}$ AMSC HSW i HSPW, taśma SF12100 ma około dwukrotnie mniejsza rezystancję od taśmy SF12050-AP, wynika to $\mathrm{z}$ różnicy $\mathrm{w}$ grubości warstwy srebra.

W obliczeniach uzwojeń w nadprzewodnikowych ogranicznikach prądu zwarciowego uwzględnia się zarówno rezystancję taśmy jak i jej pojemność cieplną. Parametry te umożliwiają obliczenie temperatury taśmy podczas zwarcia [3, 4]. Taśma SF12100-CF ma dwukrotnie grubszą warstwę podłoża w porównaniu do taśmy SF12050-AP, dzięki czemu charakteryzuje się większą pojemnością cieplną i umożliwia zaprojektowanie nadprzewodnikowego ogranicznika prądu zwarciowego na dłuższy czas zwarcia. 


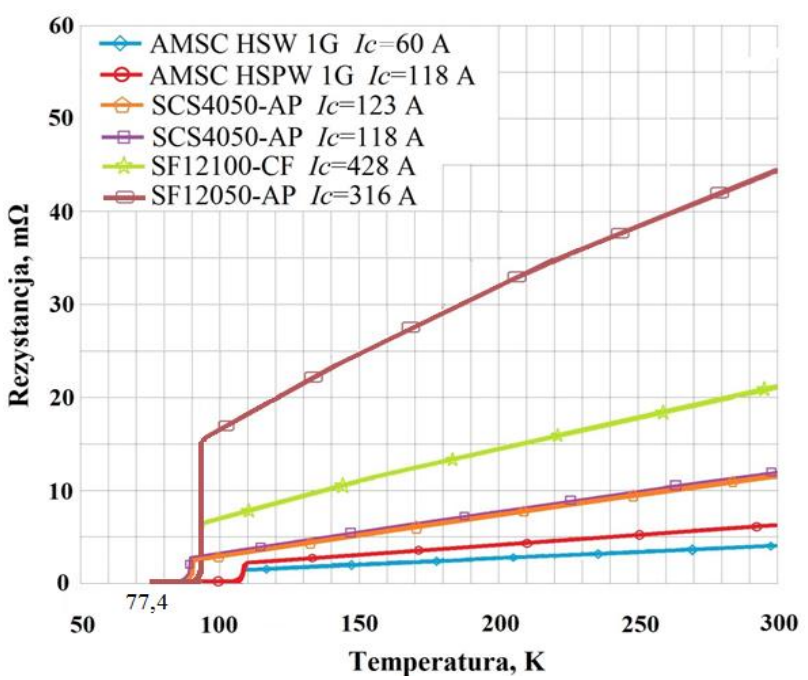

Rys. 12. Wyznaczone eksperymentalnie charakterystyki $R=f(T)$ taśm nadprzewodnikowych pierwszej i drugiej generacji (dlugość próbki $100 \mathrm{~mm}$ )

\section{Wnioski}

W artykule przedstawiono sposób przygotowania próbek taśm nadprzewodnikowych do badań, opisano metodę pomiarową i sposób wyznaczania charakterystyki $R=\mathrm{f}(T) \quad$ taśm nadprzewodnikowych. Przedstawiono unikatowe wyniki nowej, niedostępnej na rynku komercyjnym próbce taśmy nadprzewodnikowej SF 12100-CF o grubości warstwy srebra $4,5 \mu \mathrm{m}$.

Taśmy nadprzewodnikowe drugiej generacji bez stabilizatora miedzianego SF12050-AP oraz SF12100-CF sa specjalnie zaprojektowane do zastosowania $\mathrm{w}$ nadprzewodnikowych ogranicznikach prądu zwarciowego. Przy prądach roboczych prąd płynący w taśmie nadprzewodnikowej jest mniejszy od prądu krytycznego taśmy $I_{\mathrm{C}}$. W stanie nadprzewodzącym prąd płynie $\mathrm{w}$ warstwie nadprzewodnika REBCO $\mathrm{z}$ pominięciem innych warstw. Podczas zwarcia wartość prądu w taśmie kilkukrotnie przekracza wartość prądu krytycznego $I_{\mathrm{C}}$, nadprzewodnik przechodzi do stanu rezystywnego i prąd w taśmie płynie głównie przez warstwę srebra oraz podłoże. Podczas zwarcia zarówno temperatura jak i rezystancja taśmy szybko rośnie, dlatego do prawidłowego projektowania ogranicznika konieczne jest eksperymentalne wyznaczenie charakterystyki $R=\mathrm{f}(T)$.

\section{Literatura}

[1] Baldan C.A., Oliveira U.R., Shigue C.Y., Filho E.R.: Evaluation of Electrical Properties of Lap Joints for BSCCO and YBCO Tapes. IEEE Transactions on Applied Superconductivity 3(19)/2009, 2831-2834 [DOI: 10.1109/TASC.2009.2017701].

[2] Kozak J., Majka M.: Technologia łączenia taśm HTS $2 \mathrm{G}$ w uzwojeniach nadprzewodnikowych urządzeń elektrycznych. Przegląd Elektrotechniczny 3(90)/2014, 157-160 [DOI: 10.12915/pe. 2014.03.34]

[3] Kozak J., Majka M., Janowski T., Kozak S., Wojtasiewicz G., KondratowiczKucewicz B.: Tests and performance analysis of coreless inductive HTS fault

current limiters. IEEE Transactions on Applied Superconductivity 3(12)/2011, 1303-1306 [DOI: 10.1109/TASC.2010.2101033].

[4] Kozak S., Janowski T., Kondratowicz-Kucewicz B., Kozak J., Wojtasiewicz G.: Experimental and numerical analysis of energy losses in resistive SFCL. IEEE Transactions on Applied Superconductivity 2(15)/2005, 2098-2101 [DOI: 10.1109/TASC.2005.849461].

[5] Majka M., Kozak S.: Zastosowanie taśm I i II generacji do budowy nadprzewodnikowych ograniczników prądu. Przegląd Elektrotechniczny $5(89) / 2009,183-185$.

[6] Nguyen N. T., Tixador P.: A YBCO-coated conductor for a fault current limiter: architecture influences and optical study. Superconductor Science and Technology 2(23)/2010 [DOI: 10.1088/0953-2048/23/2/025008].

[7] Salazar A., Pastor J. Y., Lorca J.: Fatigue behavior of multifilamentary BSCCO 2223/Ag superconducting tapes. IEEE Transactions on Applied Superconductivity 3(14)/2004, 1841-1847, [DOI: 10.1109/TASC.2004.830606].

[8] Suarez P., Alvarez A., Ceballos J. M., Perez B.: Loss and transition studies of shunted free-stabilized YBCO tape for SFCL applications. IEEE Transactions on Applied Superconductivity 2(21)/2011, 1267-1270, [DOI:10.1109/TASC.2010.2102991].

[9] Woźniak Ł., Wojtasiewicz G., Surdacki P., Komarzyniec G., Kwoka R.: Wpływ parametrów transformatora nadprzewodnikowego na ograniczenie prąu w stanach przejściowych. Przegląd Elektrotechniczny 7(92)/2016, 61-64, [DOI:10.15199/48.2016.07.12].

[10] American Superconductor, HTS Wire [17.05.2016].

[11] Sumitomo Electric, HTS Wire, www.global-sei.com [30.05.2016].

[12] SuperPower 2G HTS Wire Specifications, www.superpower-inc.com [10.05.2016].

\begin{abstract}
Mgr inż. Rafal Kwoka
e-mail: rafal_kwoka@wp.pl

Ukończył studia magisterskie w 2012 roku na Wydziale Elektrotechniki i Informatyki Politechniki Lubelskiej. Obecnie doktorant w Instytucie Elektrotechniki i Elektrotechnologii na Wydziale Elektrotechniki i Informatyki Politechniki Lubelskiej. Zajmuje się badaniami taśm nadprzewodnikowych HTS stosowanych do budowy nadprzewodnikowych ograniczników prądu zwarciowego.
\end{abstract}

\section{Dr hab. inż. Janusz Kozak, prof. IEL}

e-mail: j.kozak@iel.waw.pl

Profesor nadzwyczajny w Pracowni Technologii Nadprzewodnikowych Instytutu Elektrotechniki. 2005-2007 pracował w CERN, gdzie zajmował sie badaniem elektromagnesów nadprzewodnikowych dla LHC. W 2009 roku pracował w CERN przy uruchomieniu akceleratora LHC. Otrzymał Nagrode Główn $w$ Konkursie ABB w $2010 \quad r$. Jest współautorem ponad 50 publikacji w tym 31 z listy filadelfijskiej. Jest współtwórcą 6 patentów.

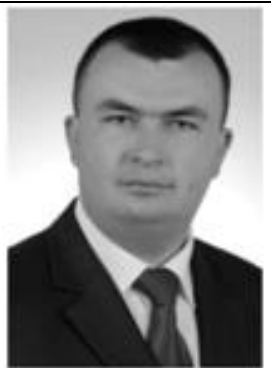

\section{Dr inż. Michal Majka}

e-mail:m.majka@pollub.pl

Adiunkt w Instytucie Elektrotechniki i Elektrotechnologii Wydziału Elektrotechniki i Informatyki Politechniki Lubelskiej, gdzie zajmuje sie projektowaniem i badaniami urządzeń nadprzewodnikowych: ograniczników prądu, elektromagnesów nadprzewodnikowych, zasobników energii oraz transformatorów. Współautor dwóch monografii, kilkudziesięciu publikacji naukowych i dwóch patentów. Brał udział w realizacji kilku projektów badawczych

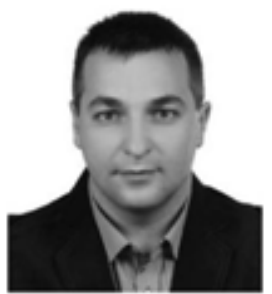

otrzymano/received: $15.06 .2015 \quad$ przyjęto do druku/accepted: 15.02 .2018 